\title{
Glass Recycling
}

\author{
Ana Franjić \\ Ian C. Freestone
}

DOI: $10.17234 / 9789531757232-10$

Reducing waste and $\mathrm{CO}_{2}$ emissions, saving energy and raw materials, and helping the environment; recycling in contemporary contexts is an imperative if we want to enjoy the future on this planet, and communities worldwide are encouraged to stay in the recycling loop. Although glass recycling has been practiced from ancient times, and glass containers were reused regularly in the nineteenth and twentieth centuries, present-day large-scale recycling started only in the 1970s (Dyer 2014: 191). The switch from the debatably more sustainable and environmentally conscious reuse to the more "convenient" recycling occurred through the promotion of technological advancements and marketing. This transition could historically be interpreted as a downgrade caused by a shift in consumption dynamics, symptomatic of our "throwaway culture" (cf. Friedel 2014), However, the aftermath of the switch is that nowadays glass is recycled almost everywhere in Europe, to varying extents.

Overall, around two thirds of all glass bottles, approximately 30 billion, are recycled each year. In 2012, the Croatian Agency for the Protection of the Environment measured that on average a Croatian citizen produces $390 \mathrm{~kg}$ of communal waste per year, which is $102 \mathrm{~kg}$ less than the average for the EU. Unfortunately, only around $16 \%$ of this waste is recycled, and about $7 \%$ of the recycled total is glass (MZOIP 2015). There are only two companies that recycle glass in Croatia, but recycling is regionally encouraged by a container deposit for PET and glass bottles which can be returned to a shop, redemption point, or recycling yards. However, glass recycling trends in Croatia are steadily growing, from less than $800 \mathrm{t}$ in 2012 to almost $1200 \mathrm{t}$ in 2015 (Čistoća 2017).

In principle, glass can be completely recycled for an unlimited number of times without losing any of its qualities: this is known as "closed-loop" recycling (Dyer 2014: 191). As to amount of resources and energy saved, it has been calculated that $1000 \mathrm{~kg}$ of recycled glass saves 700 $\mathrm{kg}$ of sand, $200 \mathrm{~kg}$ of lime, and $200 \mathrm{~kg}$ of soda; and one glass bottle gives us enough energy to power a $60 \mathrm{~W}$ bulb for 4 hours, a computer for 30 minutes or a TV for 20 minutes (Vetropack 2017). Before it is recycled, the glass cullet (scrap glass, broken glass vessels) is sorted by its colour-quality requirements to supress colourant contamination (Dyer 2014: 194) - but it is exactly these contamination traces that turn out to be useful in archaeological investigations, as further explained below. 
If we exclude the practice of grog tempering (adding crushed pottery fragments to any type of unfired clay), the first man-made material - ceramic - was not recyclable, so in the past the practice of recycling related mainly to the pyrotechnologies of metal and glass production. The secret to the recyclability of glass lies in its inherent thermodynamic characteristics. Unlike clay ceramics which are plastic and are shaped at room temperature, then are fired solid at high temperatures, glass is a stiff viscous liquid at high temperatures but becomes rigid when cooled. It can be re-heated and softened into the liquid state repeatedly to be shaped into new forms, and it is this property which makes it an ideal material for recycling.

Glassmaking requires only a few specific raw materials. Most ancient glasses comprise just three essential components and frequently these were obtained as just two ingredients. Silica, the glass-former, is found as sand or quartz minerals, but it has a very high melting point $\left(1700^{\circ} \mathrm{C}\right)$ which could not be attained in ancient furnaces. The melting point of the glass was lowered by the addition of a compatible flux, typically soda. In ancient times, soda was obtained either from naturally occurring mineral deposits such as natron, a type of sodium carbonate found in Egypt, or alternatively from the ash formed when certain plants from arid or coastal regions are burned. The soda flux breaks up the strong atomic bonds which link the silica molecules and this lowers the melting point of the glass, making it less stiff and easier to work. A pure soda-silica glass is water soluble so a third ingredient, termed a stabilizer is needed to insure the stability and durability of glass. The stabilizer typically introduced in glass was lime (calcium oxide), which could have been derived from limestone, plant ash or from marine shell found in sand. The soda-lime-silica composition was in use from the Late Bronze Age and remains the basis of many modern container and window glasses. Its simplicity has meant that it has been possible to melt glasses from many different sources together without major changes in properties, a crucial factor in being able to recycle on a large scale.

In addition to the three major ingredients, small percentages of various metal oxides, such as those of copper and cobalt, were added to give the glass colour, to decolourise it, or to make it opaque (Moretti \& Hreglich 2013: 28-32). While in principle, colourants could be added at a later time to the already produced glass, the archaeological evidence suggests that coloured glass was traded as ingots and there is very limited evidence of colourant trade per se - rather, for certain periods such as the Late Bronze Age the existence of workshops specialised in production of specific colours of glass has been hypothesized (Pusch \& Rehren 2007; Shortland 2012: 154).

Research into the chemical composition of ancient glasses provides a timeline of succession of various technological recipes, which are predominantly discernible in the type of flux used (fig. 1). Plant ash, a soda source with higher potassium levels, was in use during the second millennium BCE, and was succeeded by the purer mineral natron, retrieved from the evaporitic lakes

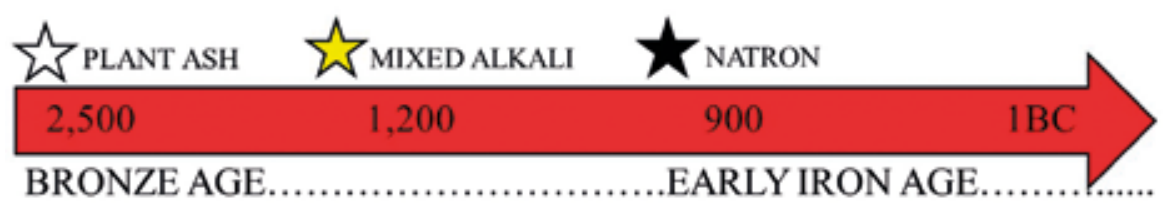

Fig. 1. General timeline showing the major types of prehistoric glass. 
Fig. 2. Compositional difference in glass types (after: Freestone 2006: 3, fig. 2).

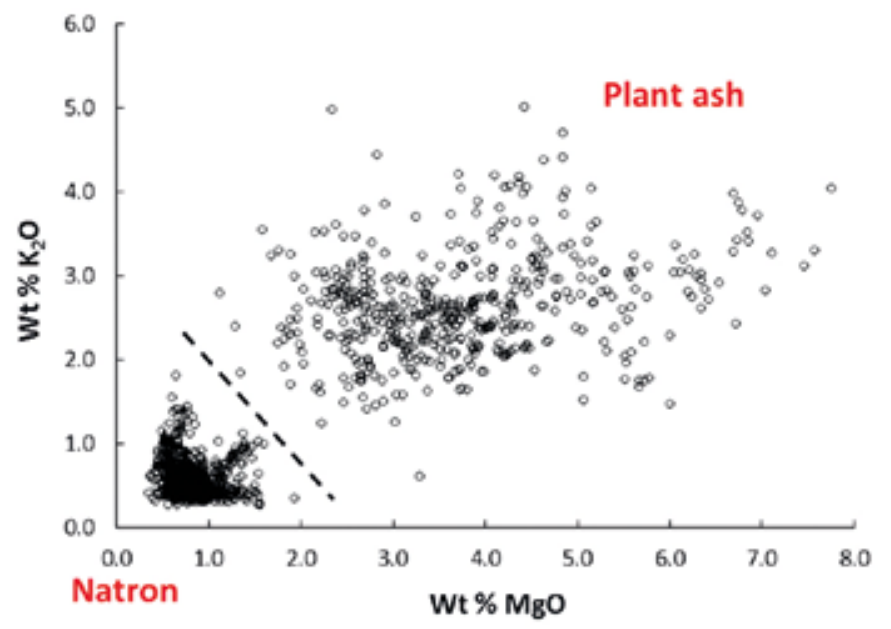

of the Wadi el Natrun and Nile Delta in Egypt, in the first millennium BCE. A short-lived occurrence of local European mixed alkali glass is recorded in LBA Italy, but was soon replaced with natron glass (Venclova et al. 2011). Natron glass was produced until around the ninth century CE, when there is once again a switch to plant ash glasses (Phelps et al. 2016). From this point glass was being made in various locations with a variety of plant ash type fluxes, which have a somewhat more complicated and variable fingerprint (Henderson et al. 2016). Glasses made from the two types of soda may in most cases be distinguished by their potash and magnesia contents (fig. 2).

\section{Practicalities of Recycling}

Recycling is a part of the chaîne opératoire of glass production, and is fundamental to the study of glass use in the past since it provides insight into the methods used by the ancient craftsmen and the mechanism of supply and demand of goods in the past (Paynter \& Jackson 2016: 32).

In ancient times glass could be recycled only a limited number of times before a fresh batch had to be added, as the loss of sodium at high temperatures would cause the viscosity of the melt to become too high, making the material too stiff for working. Secondary workshops would have had the capacity to recycle glass, as the temperatures needed to melt and mix the glass were in principle no higher than those for glass-working. Glassworkers could have recycled broken glass by adding glass cullet into a glass batch while melting it, or mixing crushed or powdered ground glass with scrap glass and then melting them together (Shortland 2012: 31, 224). A major benefit of using cullet in glass production is that it requires less energy to melt than the raw materials, and the durations and temperatures needed for recycling were significantly less than for primary glass making.

Recycling was not a homogenous practice, it would have varied in size and form within household, military, and medieval monastic contexts (Foster \& Jackson 2010: 3072; Freestone 2015: $29,34)$. Recycling was also performed for a variety of reasons, triggered not only by the lack of fresh raw materials, but by a spectrum of other motivations, as for example the recycling of coloured Roman glasses after the fourth century, to meet the demand for coloured glass (Paynter \& Jackson 2016: 46-48). However, there is now considerable evidence that Roman 
natron glass was recycled even when fresh material and the specialised knowledge of coloured glass production was still abundantly available, meaning recycling was carried out due to its economic and social advantages. Overall, the evidence for glass recycling appears greater in the western provinces, away from the primary production centres, than in the eastern provinces but this may be an effect of the extent of the more intensive study of glass in Western Europe at the present time.

\section{Reuse, Reshape, Recycle}

With respect to terminology, we should make a distinction between reuse and recycling: reuse implies "second or further use" of an item that is broken or otherwise defective in terms of its primary function, whereas recycling implies "the reuse of material in an industrial process", where the item is returned "to a previous stage of a cyclic process" (OED), and used to make a completely new thing - "so that its original identity is lost" (Degryse et al. 2006: 494).

Examples of the reuse of glass can be seen in the Iron Age Iapodean material from Lika, where fragments of glass bracelets were used as decorations on metal fibulae (fig. 3). At a later date, pieces of Roman glass objects were also often repurposed and are easily identifiable as such since they are stylistically anachronistic with respect to the rest of the object, such as the Roman jugs' mask medallions, or gold leaf decorated bowls bases, turned into "keepsakes, lids and counters" (Paynter \& Jackson 2016: 36). Remnants of this practice has been documented in Switzerland, Israel, France, Germany, and Great Britain. Some Roman glass fragments, like the ones retrieved in Augusta Raurica in Switzerland, as well as several sites in Syria and Belgium, resemble lithic tools. The use for these pieces is still unknown, but could possibly have been related to textile, leather and fur processing, or, alternatively, ceramic decoration and/or basket weaving (Fünfschilling 2015: 171, 174-6).

Examples from the modern period include nineteenth-century Aboriginal Australian arrowheads, spearheads and knife blades, which were pressure-flaked from discarded European bottles, as well as the reuse of beer bottles as jam jars in first half of the twentieth century in the Otway Ranges in Australia (Stuart 1993: 17; Harrison 2004: 1; Harrison 2006: 65).

Glass cullet was sometimes repurposed altogether and used as a flux in metal production: cross-craft interactions between metallurgists and glassmakers and the use of one material in the production of the other was quite frequent. Glass was used to facilitate the assaying and

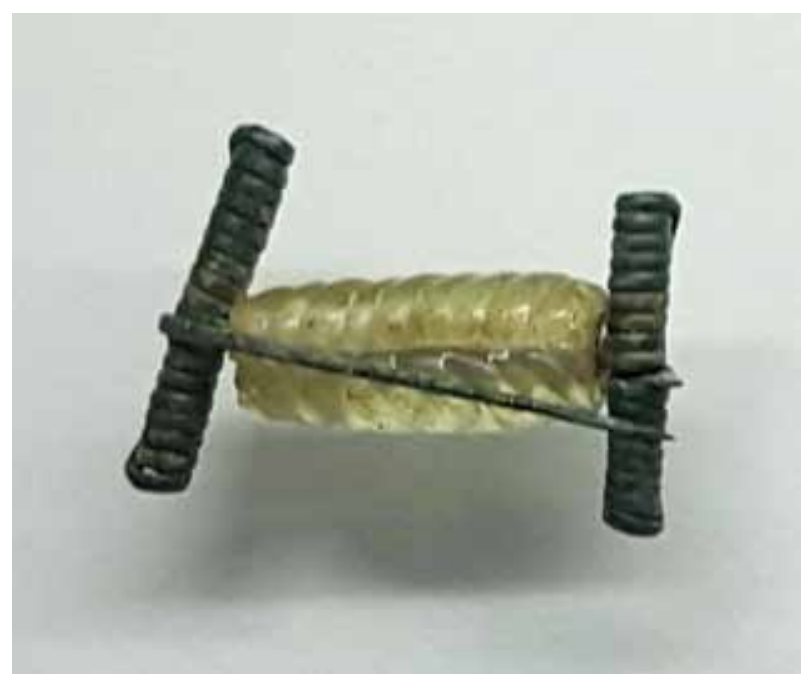

Fig. 3. lapodean fibulae decorated with glass bracelet fragments - an example of glass reuse (photo: A Franjić). 
Fig. 4a-b. Microphotographs of slag inclusions in lapodean eye beads (scanning electron microscope: A Franjić).
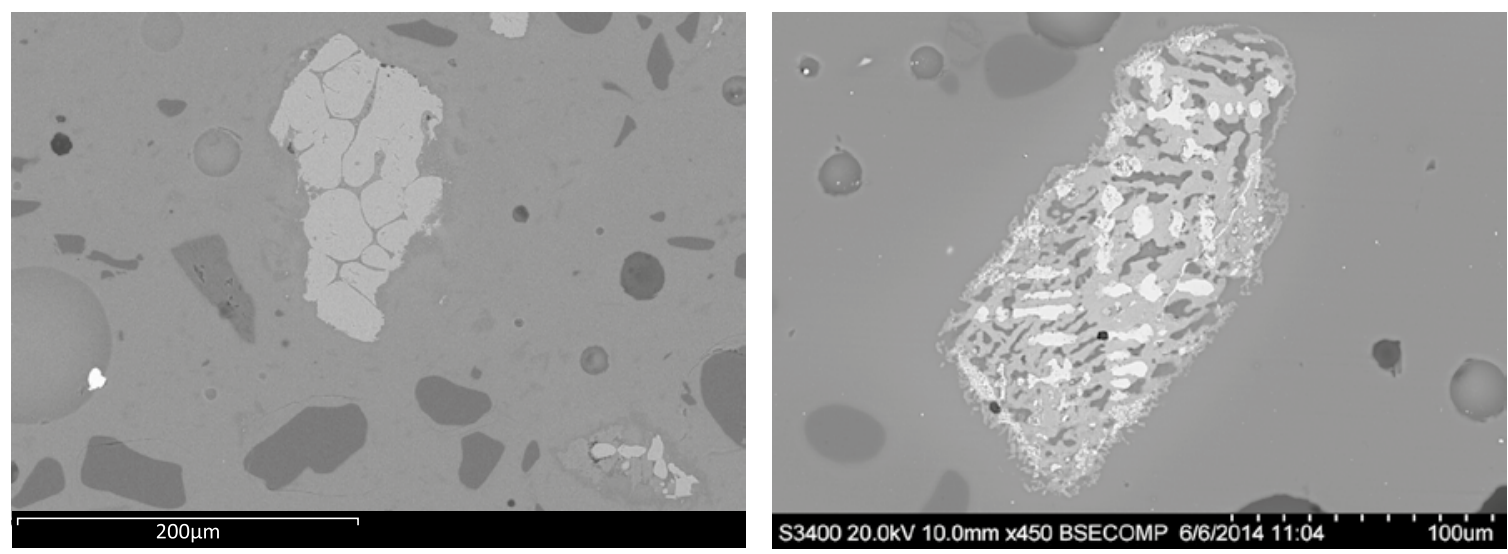

smelting of noble metals in the Renaissance, which was also advised by Agricola in his De re Metallica (Hoover \& Hoover 1950: 238; Mongiatti et al. 2009: 40; Dyer 2014: 199). Use of crushed glass beads as a flux to facilitate the agglomeration of the individual gold flakes in the gold refining process has also been documented in an early Islamic context at the Tadmekka site in the present-day Republic of Mali, while a similar practice of gold aggregation, with borax instead of glass beads, still exists in the area today (Rehren \& Nixon 2014: 33, 37-8). Conversely, use of metallurgical slag as colourant is documented in the cases of Iron Age Iapodean eye beads (Franjić \& Freestone 2017: 138; figs. 4a-b), early Anglo-Saxon opaque red glass (Peake \& Freestone 2012) and Roman glass from Serdica (Cholakova \& Rehren 2012).

Enamelled twelfth-century metalwork provides evidence of connection between the recycling of Roman glass mosaic tesserae and enamelling practice (Freestone 2015: 37). However, it is interesting to note that red enamels were freshly made in contemporary workshops from plant ash glass coloured with copper, suggesting recycling tesserae for other colours was due to the lack of appropriate pigments and/or knowledge to produce the desired colour (Freestone 2015: 38). The use of tesserae in enamelling terminates around $1200 \mathrm{CE}$, probably due to a shortage in supplies of old Roman glass, mirrored also in the discontinuation of tesserae recycling for the production of stained glass windows at about the same time (Freestone 2015: 39).

\section{The origins of recycling}

It is possible that an understanding of the potential of glass to be recycled first occurred in primary workshops, where the craftsmen started recycling waste products of glass production (Degryse et al. 2006: 494). The reasons for adoption of the practice were probably of a technical and economical nature: shortage of raw material, availability of scrap glass in the vicinity, decreased cost of production. Stern (1991: 441, 450-51) suggests that the discovery of recycling was closely related to the realisation that molten glass can be blown, and the invention of glassblowing, whereas earlier recycling practices involved only reuse and not re-melting. This hypothesis remains to be fully investigated; however, there is compositional evidence suggestive of recycling in Hellenistic cast bowls, produced before the introduction of glass blowing in the first century BCE (eg. Reade \& Privat 2016). 
Evidence (if any) for recycling of prehistoric glass must be sought in the archaeological record. Although early Mesopotamian and Egyptian texts offer instructions on how to make glass and illustrate its value, they do not mention recycling (Paynter \& Tite 2001: 240, 253; Shortland 2012: 56, 122-125;). Recycling practice can be confirmed with certainty only from the first century CE, although it is implausible to assume that prehistoric craftsmen did not notice the potential of recycling themselves. However, in the Flavian period we see the rise of cullet collection and trade, which possibly becomes more noticeable due to the rise of large-scale glass production following the invention of glassblowing (Silvestri 2008b: 1489). Roman glass production was monumental in scale: for example, $16,900 \mathrm{~m}^{2}$ of glass were required only for the mosaic in the Baths of Caracalla in Rome (DeLaine 1997).

The first-century CE poets Martial, Statius, and Juvenal offer insights into recycling routines of the Romans, mentioning street vendors trading sulphur (used for matches) for broken glass (Juvenal \& Persius 1928: 73; Martial 1993: 67; Keller 2005: 67; Statius 2015: 69). However, recycling is not mentioned in the elaborate description of glassmaking processes in Pliny's Natural History (ca. 77-79 AD), suggesting that he was still unaware of the existence of the practice (Natural History 36.199; Stern 1999: 451). Cassius Dio (1955: 411) recounts that during Claudius' reign obtaining Roman citizenship became as cheap and easy as "giving the right person some bits of broken glass". Epigraphic evidence from the third century CE references a soldier from the Legio XIV Gemina in Carnuntum who was making windows, attesting to the Roman army's practice of recycling glass for their needs, to avoid dependency on long-distance trade (Keller 2005: 67-8). Low profit in glassblowing handicraft after the introduction of Diocletian's price edict might have been the reason for a boost in glass recycling (Stern 1991: 464).

Recycling of Roman glass is likewise mentioned in medieval texts, most notably in Theophilus' twelfth-century treatise De diversis artibus, describing how coloured glass mosaic tesserae are diluted with fresh glass in the production of blue stained windows (Hawthorne \& Smith 1976: 59). Furthermore, Eraclius, writing on the arts of painting, describes how molten Roman glass is pressed into clay moulds to "make beautiful shining gems" (Merrifield 1999: 196). An example of this practice is seen in the head reliquary of St. Eustace from the Cathedral Treasury of Basel (Joyner et al. 2006).

\section{Traces of Recycling in the Archaeological Record}

While physical evidence of recycling such as collected broken glass and leftovers from the glassmaking process would have been present in glass workshops, it is likely to be most visible in the archaeological record only in the case of sudden abandonment of the site (e.g. Schibille \& Freestone 2013: 1). The poor quality of the glass produced in the Middle Kingdom Pyramid complex at Lisht, south of Cairo, where fragments of Egyptian Blue, faience, glass, rods, and runs (leftovers from the production process) were discovered, has been interpreted as the result of glass recycling (Shortland 2012: 97). Known examples of stored scrap glass from later dates include the workshops in the Levant and the two shops in Sardis (Turkey) (Degryse et al. 2006: 495), while the earliest documented scrap glass comes from a pit deposit at Gresham Street (50-60 CE), Regis House (65-70 CE) and Watling House (50-100 CE) in London, all situated on the periphery of the city (Shepherd 2015: 42-3), and Pompeii (79 CE) (Degryse et al. 2006: 495).

In the Roman period glass cullet was collected on different scales and in different contexts. There are many known cullet assemblages discovered in military camps, villas and towns (Wardle et al. 2015; Paynter \& Jackson 2016: 35; Keller 2005: 66). Cullet left at the military camp in Nijmegen, after the legion moved, indicates broken glass was not worth transporting, 
but was collected on site as needed (Keller 2005: 69). Towns in Italy display a complex model of scattered, small glass-recycling activities, for example in the vicinity of Aquileia, a famous glassworking centre. Glassblowing waste dated to fourth century CE was found in Sevegliano near Aquileia, as well as in a domestic context in the Domus delle Bestie Ferite (first to fifth century CE), where glass tesserae were used to make beads, and tesserae mixed with window glass to make ornaments. This assemblage, along with the seventh-century glass from Roman villa of Aiano near Siena, demonstrates that the recycling of tesserae from mosaics was already taking place before the medieval period (Boschetti et al. 2016: 72, 84-5).

Furthermore, substantial demand for scrap glass, and the practice of its collection in various locations is indicated by the shipwreck of Iulia Felix (third century CE), which was carrying a large cargo of glass cullet, as well as by the large amounts of cullet $(70 \mathrm{~kg}$ ) unearthed at Guildhall in London (first to fourth century CE). Negative evidence of the lack of broken glass in some archaeological contexts can also be taken to indicate routine collection and recycling of glass in the Roman period (Keller 2005: 68).

During the Byzantine period churches had an important economic role in scrap glass collecting and recycling. Although broken holy vessels had to be buried, glass from lamps and windows was collected, as is documented in several sacral architectural complexes in Jordan. The demand for glass was still high, so glass collection and storage within the church's perimeter was necessary in order to provide for and maintain the large monastic estates (Keller 2005: 69-74). Glass recycling practices were simultaneous to use of imported fresh glass during the seventh century, and evidence for recycling intensifies in the early eighth century (Freestone 2015: 35). Recycling of Roman glass continued throughout the early medieval period. Primary production of natron-based glass in the eastern Mediterranean ended by the middle of the ninth century (Phelps et al. 2016), and it was replaced with soda plant ash glasses in the South and potashbased glass in the North, but the demand for coloured window panes called for the recycling of Roman coloured glass, as seen for example in the monastery of San Vincenzo in South Italy (Schibille \& Freestone 2013). On the other hand, re-melting Roman tesserae as a source of glass material, and not colour, is documented in the ninth-to tenth-century vessels from Anglo-Saxon contexts of modern-day Southampton which have elevated levels of transitional metals (Freestone 2015: 36).

Fig. 5. Nineteenth-century table top by $\mathrm{G}$. Rossignani, made of hundreds of ancient glass cuts. Corning Museum of Glass 97.3.10 (photo: I Freestone).

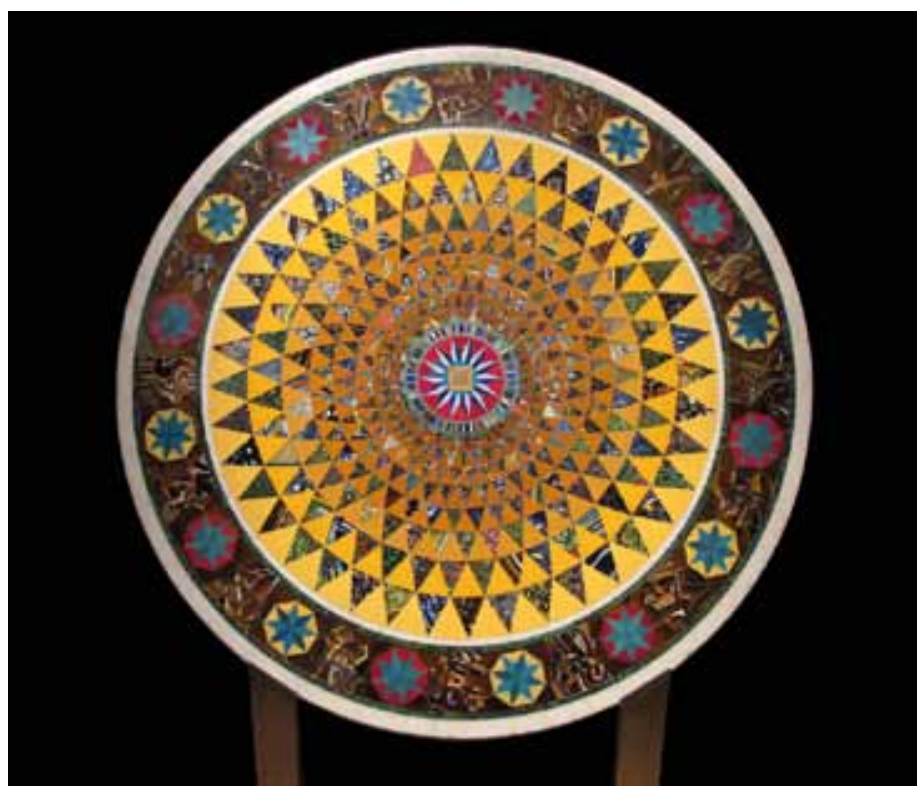


In the Islamic world, a 3-tonne cargo of glass dating to the eleventh century and including cullet for re-melting is documented in the Serce Limani shipwreck, off southern Turkey (Bass et al. 2009). Cullet collection is also documented in eighteenth-century French workshops, and is still practiced in contemporary workshops in Cairo and Damascus (Keller 2005: 68). Roman glass kept its allure long after the Middle Ages and the symbolic power of Roman glass is materialised in a nineteenth-century table top by Venetian Giovanni Rossignani, made of hundreds of Hellenistic and Roman glass cuts (fig. 5). Roman glass is still valued today and continues to be (re)used for fine jewellery (Freestone 2015: 39).

\section{Using glass composition to recognise recycling}

Current investigations of glass recycling in the ancient world are heavily dependent upon the evidence of scientific analysis. The organisation of production is the first step in the understanding of the dynamics of glass use. The centralised production of raw glass, with only a few large glassmaking sites located near raw material sources in the Mediterranean, appears to have been a standard model of glass production until medieval times. These primary production workshops made glass from raw materials, and then traded the glass in the form of ingots (LBA, EIA) or lumps (Roman period; fig. 6) to the more common secondary glass workshops situated throughout Europe and the Mediterranean, which worked the raw glass into finished objects.

The existence of a relatively small number of primary production centres, in specific geographical locations with distinct compositional features (for example slightly different amounts of components such as $\mathrm{CaO}, \mathrm{Al}_{2} \mathrm{O}_{3}$ or $\mathrm{TiO}_{2}$ ) provides a framework within which recycled glass may be identified. Nonetheless, recognising ancient glass recycling poses many challenges, the most obvious one being the invisibility of a large scale and efficient recycling system. Efficient recycling implies repeated re-melting and mixing of glasses from a range of sources, so all glass recovered from a specific period in the archaeological record would have gone through numerous cycles of mixing and re-melting and converged upon a single hybrid composition without traces of the original characteristics of the individual furnaces. Truly efficient recycling can therefore leave no obvious trace of the process in the composition of the glass. We are dependent upon the failure of societies to behave in such an efficient manner to detect and understand the process. Inevitably glass artefacts are recovered which were made from fresh glass which

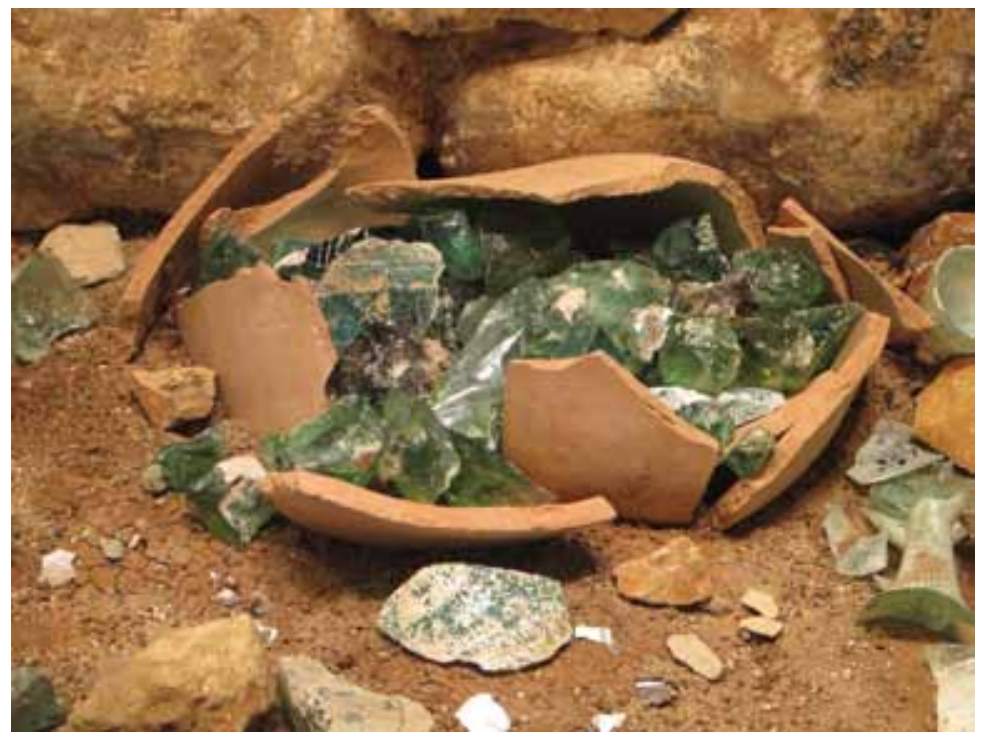

Fig. 6. Chunks of raw glass found in a Byzantine glass workshop at Beth Shean, Israel and on display in the Israel Museum (photo: I Freestone). 
Fig. 7. Major glass compositional groups of the first millennium CE. Each colour symbol represents the products of a distinctive production centre (after: Freestone et al. 2018).

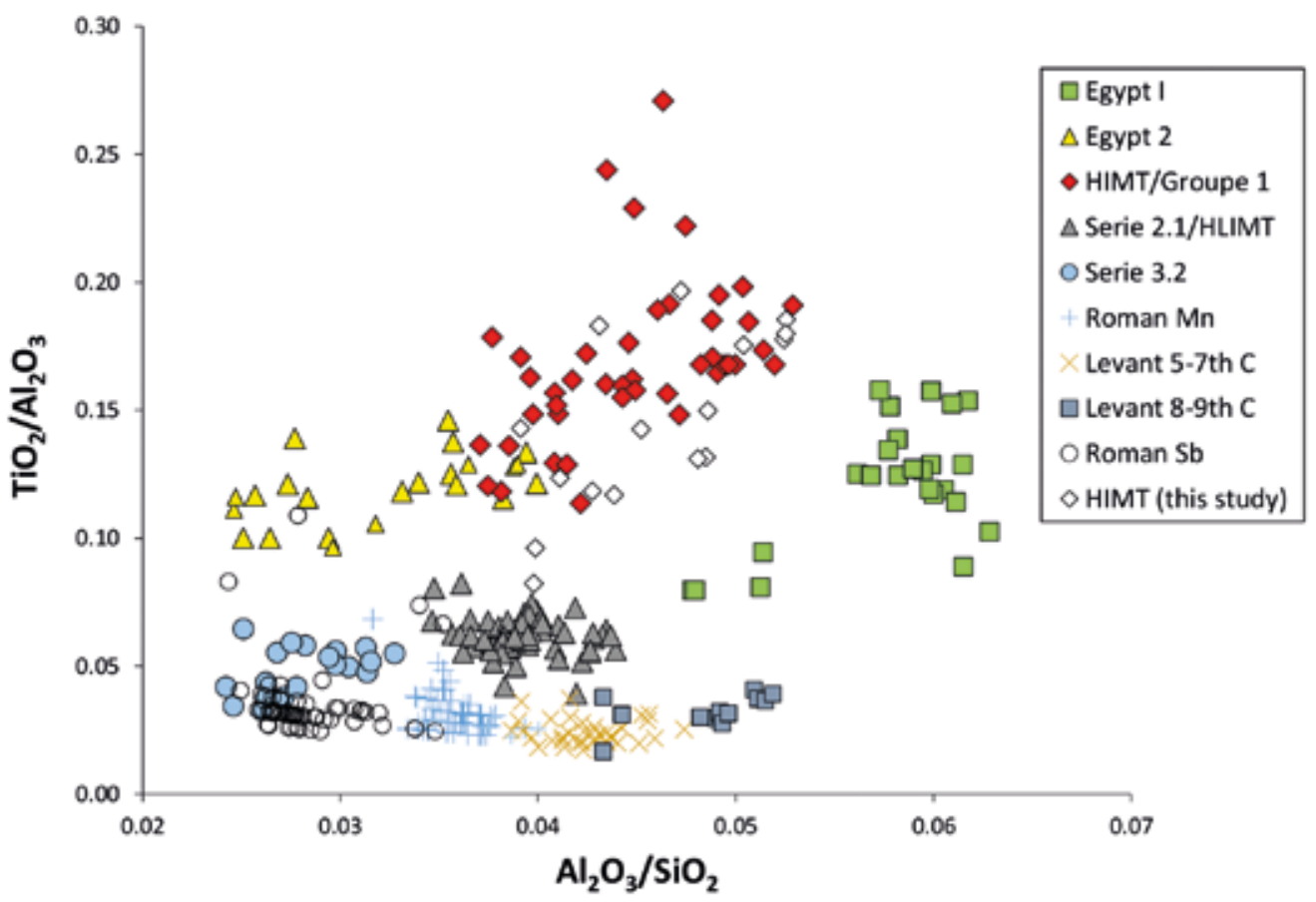

had undergone minimal recycling. These may be used to establish the primary glass compositional groups, representing fresh glass from the primary production workshops (e.g. fig. 7). Recycled glass may then be identified as compositions which are mixtures of these primary groups.

In many cases the glass used in a region at a specific time may be derived from a single primary glass source. Then, even after many cycles of mixing and re-melting, the bulk glass composition will still reflect the primary production centre. To confirm that the glass was recycled, the compositional clues that must be sought include the contamination of the glass by the unintentional incorporation of coloured glass in the recycled material. This coloured glass may have been added in the form of handles or decorative threads on otherwise plain recycled vessels, or as coloured mosaic tesserae, bangles or beads which were included because they extended the amount of glass available but, in relatively small quantities, did not affect the colour of the glass. An example might be a vessel of green glass coloured by two per cent copper oxide, $\mathrm{CuO}$. Addition of just one percent of this copper green glass to a batch for recycling will elevate the bulk copper content of the recycled glass from around 50 parts per million to about 200 parts per million. Such a low concentration of copper will have a barely detectable effect on the colour of the glass but the change will be relatively easy to detect using modern methods of analysis and is a clear indication of the presence of recycled glass. Other colourants, such as lead, antimony, cobalt and tin are also modified by such imperfect recycling practices and taken together provide a good fingerprint for the recycling process.

In addition to the mixing of different primary glass types and contamination by coloured glass, simply re-melting glass may result in some compositional change, due to loss of elements that are volatile at high temperatures such as sodium or chlorine, contamination by fuel ash which 
can add elements such as potassium and phosphorus or contamination from the melting pot or furnace wall (Jackson \& Paynter 2016; Al Bashaireh et al. 2015). There is no reason for a single artefact to be reheated, so re-melting implicitly indicates a recycling process.

The foregoing indicates that the recognition of recycling is far from straightforward. While we may in many cases identify that recycling has occurred, we are still limited in our ability to determine the intensity of the process, that is, how many episodes of mixing and re-melting have occurred. While patterns of recycling are evidence of "social, economic and inter-regional relationships in the past" (Schibille \& Freestone 2013: 1), we are far from providing the quantification needed to robustly assess its importance in the ancient economy.

\section{Case Studies: Glass composition and recycling}

\section{Roman Transparent Glass}

It has been recognised for some time that Roman colourless glass of $1^{\text {st }} 4^{\text {th }}$ centuries CE comprises two main types: Rom-Sb, decolourised by the addition of around one per cent antimony oxide, and Rom-Mn, characterised by around one per cent manganese oxide. The two types differ in other ways, in terms of their levels of soda, lime and alumina (fig. 7), and it appears that they were produced in two primary production centres. Current thought seems to be converging on the idea that Rom-Sb was made in Egypt (Degryse 2014; Schibille et al. 2017) while the Mn-variety was produced in Palestine, as suggested some years ago by Nenna et al. (1997).

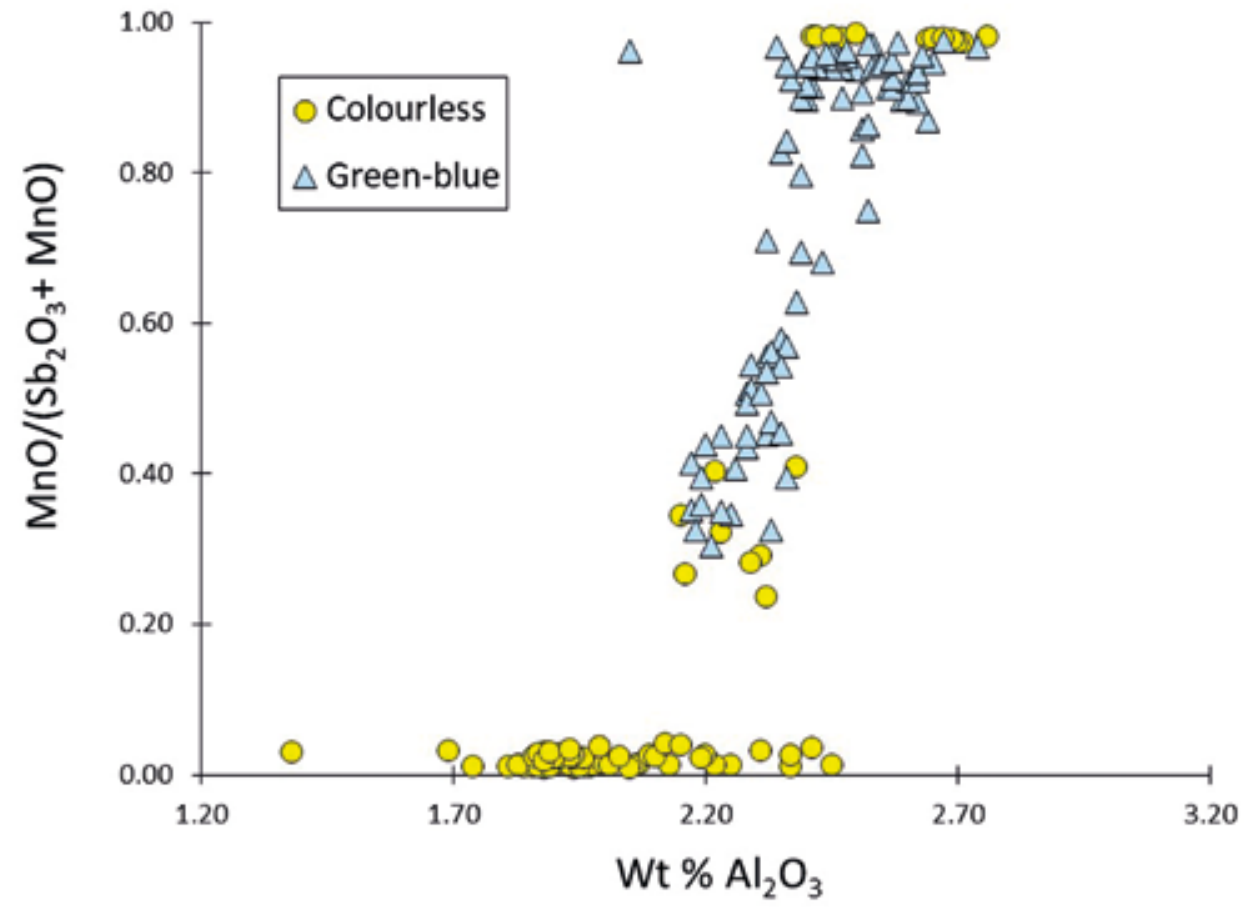

Fig. 8. Manganese- and antimony-decoloured glass of the lulia Felix plotted against the alumina content, showing the mixing line between the low-alumina antimony-decolorized glass and the high-alumina manganese-decolorized glass (after: Freestone 2015: 32, fig. 2). 
The bulk of Roman transparent glass, however, is not colourless but green-blue, and much of this contains both antimony and manganese. As inferred by Silvestri et al. (2008a, b) and by Jackson \& Paynter (2016) in their study of first- to fourth-century colourless glass from Roman Coppergate, this glass, which contains both decolourisers, is likely to be recycled; a mixture of Rom-Mn and Rom-Sb.

An example is provided by the Iulia Felix ship, sunk near Grado (Udine, Italy). It carried a $1.4 \mathrm{~m}$ high wooden barrel, with over 11,000 fragments of glass vessels of various types, mostly naturally coloured, with fewer fragments of transparent glass, and rare dark glass fragments. The limited variety of glass indicates sorting to prevent colourant contamination, and possibly suggests that glass might have been collected to serve orders requiring certain weight of a certain glass type (Silvestri et al. 2008a: 335). This is the first documented example from the Roman period of recycling glass carried on cargo ships, whereas other studied wrecks carried only raw glass and fine tableware (Silvestri et al. 2008a: 331, 332; Silvestri 2008b: 1492). The two types of colourless glass were identified: Rom-Sb seems to have comprised high-quality vessel cullet, while Rom-Mn and mixed Mn-Sb glass comprised lower-grade container cullet (Silvestri et al. 2008a: 331). Silvestri's data are re-plotted in fig. 8, which shows a linear relationship, or mixing line, between the Mn-rich and Sb-rich glasses. It appears that the antimony decolourisation produces a much more stable colourless glass than the manganese, as most of the green-blue tinted glasses lie closer to the Rom-Mn compositions. Furthermore, it looks as if the Roman glassworkers tried to keep the higher quality antimony decolourised glass unadulterated by manganese-bearing glass where possible, as there is a gap in the trend towards the Rom-Sb composition.

A more complex situation was recorded by Jackson \& Paynter (2016) in the glass from York. These authors observed the mixing of antimony and manganese-bearing glasses and raised levels of copper and lead in the mixed glasses, indicating contamination by coloured glass. However, they were able to infer from the range of concentrations "different recycling histories": some of the glass had been recycled at least twice-first as colourless and then with the naturally coloured batch (Jackson \& Paynter 2016: 78). The high amount of recycled glass suggests limited access to fresh glass in Britain, as well as the custom of more frequent use of fresh glass for the production of fineware, and recycled glass for the low-status everyday ware (Jackson \& Paynter 2016: 82).

\section{Early Medieval Glass from San Vincenzo al Volturno}

A later, ninth-century example is the glass from a workshop at the Monastery of San Vincenzo al Volturno, Molise, Southern Italy (fig. 9). Hundreds of glass tesserae from mosaics were found along with used crucibles, some containing the partially melted remains of tesserae. The absence of glass mosaics indicate that the tesserae were collected to be recycled as a source of glass and/or colourants (Schibille \& Freestone 2013: 2, 8, 11) and they were dated to the first to third century based on their composition (no traces of the tin opacifier, which is typically used after the fourth century). The study shows that the blue windows of the monastery were formed by melting tesserae, as documented by Theophilus for the later medieval period (Schibille \& Freestone 2013: 7-8).

Furthermore, it was shown that the glass worked on the site comprised three compositional groups: one equivalent to a mixture of molten tesserae, one equivalent to third-century RomMn glass which had undergone minimal recycling, and a mixture of these two types. This pointed to the use of scavenged Roman glass removed from a single source-a large Roman building which had extensive wall mosaics and glass windows, the windows providing the Rom-Mn type glass. Such an origin would be consistent with the widespread use of spolia in architecture at 
Fig. 9. Glass items and working waste from San Vincenzo al Volturno (after: Schibille \& Freestone 2013: 3, fig. 1).

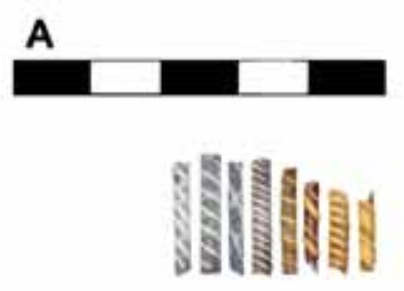

B

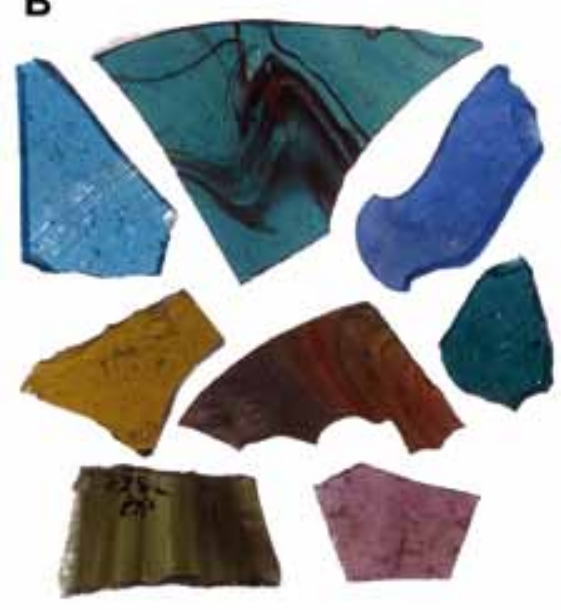

C
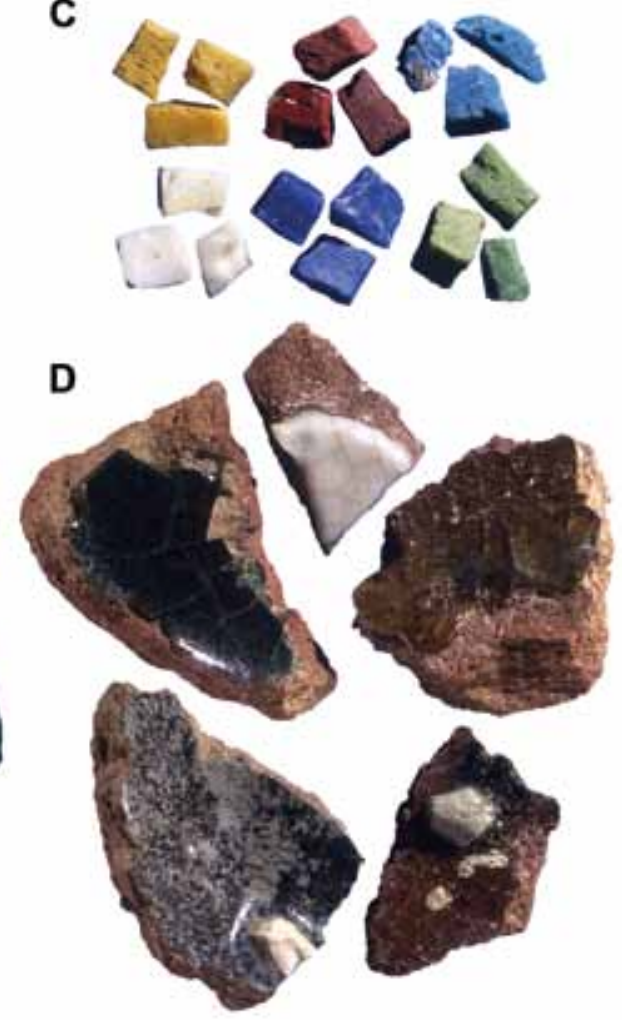

the time. In the twelfth-century Chronicon Vulturnense, abbot Giovanni recounts how San Vincenzo was given a Roman temple in Capua, whose columns were used in the construction of the church (cf. Giovanni \& Federici 1925; Schibille \& Freestone 2013: 11).

Recycling glass from trade beads

Some interesting examples of glass recycling may be found in the practices of indigenous peoples who first encounter glass in the form of trade beads and have no local glass-making industry of their own. For example, analysis of trapezoidal blue glass pendants used by the indigenous peoples of North American Upper Great Lakes has indicated that they were produced by crushing and re-melting European glass trade beads during the early years of European contact in the seventeenth and eighteenth centuries (Walder 2013: 365-366).

A similar situation appears to have occurred in southern Africa where large numbers of IndoPacific beads of a specifically South Asian composition, comprising a mineral soda-lime-silica glass with high alumina, are found in tenth- to thirteenth- century contexts. Also present is a type of locally made bead, the Garden Roller, so-called because of its resemblance to the lawn levelling device of the same name (Wood 2016). In a comprehensive investigation of the chemistry of beads from southern Africa, Robertshaw et al. (2010) were able to show that the garden rollers were produced by recycling the glass from the Indo-pacific beads. The method of production varied; the Indo-Pacific beads could be crushed or melted whole in clay moulds to produce the larger garden rollers (Wood 2016). 
These examples of recycling, from very different places and periods, suggest that when people are confronted with a new material such as glass, a process of exploration occurs which may eventually allow them to manipulate it in a creative fashion to produce their own artefacts. They provide clues as to how the technological transfer of glass technology may have occurred in the past.

\section{Conclusion}

Although there are many uncertainties and limitations in the study of the mechanisms of ancient recycling, technological analyses of chemical compositions and isotopic ratios in glass artefacts do offer us a key for deciphering at least a minute part of the glasses' life histories. As some of the presented case-studies hopefully demonstrate, recycling as a process cannot be explained as simply a consequence of the lack of fresh material, but is influenced by many other social and situational factors. Production, use, discard and re-use of glass, or any material in that respect, is firmly embedded in the larger social, cultural, environmental and economic practices of ancient societies.

Recycling is an essential part of the chaîne opératoire of glass production. The scale and patterns of recycling shed light on the systems of procurement, organisation of production, technological choices, the extent of knowledge of the ancient craftsmen, and the overall demand for glass in a society. These trends have determined trade systems, developed local economies, and influenced the life-histories of glass artefacts. The cycles of use and reuse of a material offer information about regional relationships and map not only the rise and decline in the prominence of a certain material, but also the changes in traditions, adaptations to demand and different specialised tasks. These kinds of information make a valuable contribution to our knowledge about the past technologies and societies, upcycling the present understanding of the social values and worldviews hidden in the archaeological record. 


\section{Bibliography}

Agricola, G. M. N., Hoover, H. C. \& Hoover, L. H. 1950. De re metallica. Dover. New York.

Al-Bashaireh, K., Al-Mustafa, S., Freestone, I. C. \& Al-Housan, A. Q. 2016. Composition of Byzantine glasses from Umm el-Jimal, northeast Jordan: Insights into glass origins and recycling. Journal of Cultural Heritage 21. 809-818.

Bass, G. F., Lledo, B., Brill, R. H. \& Matthews, S. 2009. Serçe Limani, Vol 2. The Glass of an EleventhCentury Shipwreck. College Station. A\&M University Press. Texas.

Boschetti, C., Mantovani, V. \& Leonelli, C. 2016. Glass Colouring and Recycling in Late Antiquity: A New Case Study from Aquileia (Italy). Journal of Glass Studies 58. 69-86.

Cassius Dio, 1955. Roman History. Transl. Earnest Cary. MA: Harvard University Press. Cambridge.

Cholakova, A. \& Rehren, T. 2012. Producing black glass during the Roman period-notes on a crucible fragment from Serdica, Bulgaria. Proceedings of the 39th International Symposium for Archaeometry. Leuven. 261-267.

Čistoća, 2017. Staklo. Available at: http://www.cistoca.hr/arhiva/stariweb/staklo/1343 (Accessed 20 April 2017)

Degryse, P. 2014. Glass Making in the Greco-Roman World: Results of the ARCHGLASS Project. Leuven University Press. Leuven.

Degryse, P., Schneider, J., Haack, U., Lauwers, V., Poblome, J., Waelkens, M. \& Muchez, P. 2006. Evidence for glass 'recycling' using $\mathrm{Pb}$ and $\mathrm{Sr}$ isotopic ratios and $\mathrm{Sr}$-mixing lines: the case of early Byzantine Sagalassos. Journal of Archaeological Science 33. 494-501.

DeLaine, J. 1997. The baths of Caracalla. A study in the design, construction and economics of large-scale building projects in imperial Rome. Journal of Roman Archaeology suppl,25. RI: JRA. Portsmouth.

Dyer, T. D. 2014. Glass Recycling. In: Handbook of recycling: state of-the-art for practitioners, analysts, and scientists. (eds. E. Worrell, M. A. Reuter). Elsevier. Amsterdam, Boston. 191-209.

Foster, H. E. \& Jackson, C. M. 2010. The composition of late Romano-British colourless vessel glass: glass production and consumption. Journal of Archaeological Science 37. 3068-3080.

Franjić, A. \& Freestone, I. C. 2017. Iapodean Beads Inside and Out. In: Iapodes - the forgotten highlanders. (ed. L. Bakarić). Exhibition Catalogue. Archaeological Museum in Zagreb. Zagreb. 135-139.

Freestone, I. C. 2006. Glass production in Late Antiquity and the Early Islamic period: a geochemical perspective. In: Geomaterials in Cultural Heritage. (eds. M. Maggetti \& B. Messiga). The Geological Society. London. 201-216.

Freestone, I. C. 2015. The Recycling and Reuse of Roman Glass: Analytical Approaches. Journal of Glass Studies 57. 29-40.

Freestone I. C., Degryse, P., Lankton J., Gratuze, B. \& Schneider J. (in press for 2018)

HIMT, glass composition and commodity branding in the primary glass industry. In: Things That Travelled: Glass in the First Millennium CE. (eds. D. Rosenow, M. Phelps, A. Meek \& I. C. Freestone.). UCL Press. London.

Friedel, R. 2014. American Bottles: The Road to no Return. Environmental History 19 (3). 505527.

Fünfschilling, S. 2015. The Re-Use of Roman Glass Fragments. In: Glass of the Roman World. (eds. J. Bayley, I. C. Freestone, C. Jackson). Oxbow. Oxford. 170-177.

Giovanni \& Federici, V. 1925. Chronicon vulturnense del monaco Giovanni. Tipografia del Senato. Roma. 
Grose, D. F. 1989. Early ancient glass: core-formed, rod-formed, and cast vessels and objects from the late Bronze Age to the early Roman Empire, 1600 B.C. to A.D. 50. Hudson Hills Press in association with the Toledo Museum of Art. NewYork.

Hawthorne, J. G. \& Smith, C. S. 1976. Theophilus: On Divers Arts. University of Chicago Press. Chicago.

Harrison, R. 2004. Kimberley Points and Colonial Preference: New Insights into the Chronology of Pressure Flaked Point Forms from the Southeast Kimberley, Western Australia. Archaeology in Oceania 39. 1-11.

Harrison, R. 2006. An Artefact of Colonial Desire? Kimberley Points and the Technologies of Enchantment. Current Anthropology 47. 63-88.

Henderson, J., Chenery, S., Faber, E. \& Kröger, J. 2016. The Use of Electron Probe Microanalysis and Laser Ablation-Inductively Coupled Plasma-Mass Spectrometry for the Investigation of 8th-14th Century Plant Ash Glasses from the Middle East. Microchemical Journal 128. 134-152. Jackson, C. M. \& Paynter, S. 2016. A Great Big Melting Pot: Exploring Patterns of Glass Supply, Consumption and Recycling in Roman Coppergate, York. Archaeometry 58. 68-95.

Joyner, L., Freestone, I. C. \& Robinson, J. 2006. Crowning glory: the identification of gems on the head reliquary of St. Eustace from the Basle Cathedral Treasury. Journal of Gemmology 30. 169-182.

Juvenal \& Persius, 1928. Juvenal and Persius. (trans. G. G. Ramsay). Heinemann. London.

Keller, D. 2005. Social and Economic Aspects of Glass Recycling. In: TRAC 2004: Proceedings of the Fourteenth Annual Theoretical Roman Archaeology Conference, University of Durham. (eds. J. Bruhn, B. Croxford \& D. Grigoropoulos). Oxbow. Oxford. 65-78.

Martial, 1993. Epigrams. (trans. D. R. Shackleton Bailey). MA: Harvard University Press. Cambridge.

Merrifield, M. P. 1999. Medieval and Renaissance treatises on the arts of painting: original texts with English translations. Dover Publications. Mineola. N.Y.

Mongiatti, A., Martinon-Torres, M. \& Rehren, T. 2009. Testing Ores for Gold and Silver in Renaissance Austria: New techniques, new discoveries. Proceedings of the $36^{\text {th }}$ International Symposium for Arcaheometry, Quebec (2006). 37-49.

Moretti, C. \& Hreglich, S. 2013. Raw Materials, Recipes and Procedures Used for Glass Making. In: Modern Methods for Analysing Archaeological and Historical Glass. Volume I. (ed. K. Janssens). John Wiley and Sons Ltd. Oxford. 23-47.

MZOIP 2015. Priopćenje za javnost: Recikliranjem stakla do gospodarskog rasta i zelenih radnih mjesta. Available at: http://www.mzoip.hr/hr/ministarstvo/vijesti/recikliranjem-stakla-dogospodarskog rasta-i-zelenih-radnih-mjesta.html (Accessed 20 April 2017).

Nenna, M-D., Vichy, M. \& Picon, M. 1997. L'Atelier de verrier de Lyon, du 1er siècle après J.-C., et l'origine des verres "Romains". Revue d'Archéométrie 21. 81-87.

Phelps, M., Freestone, I. C., Gorin-Rosen, Y. \& Gratuze, B. 2016. Natron glass production and supply in the late antique and early medieval Near East: The effect of the Byzantine-Islamic transition. Journal of Archaeological Science 75. 57-71.

Pliny 1962. Natural History, Volume X: Books 36-37. (trans. D. E. Eichholz). Loeb Classical Library 419. MA: Harvard University Press. Cambridge.

Pusch, E. \& Rehren, Th. 2007. Rubinglas für den Pharao. Forschungen in der Ramses Stadt, Band 6. Vol 1, Text. Gerstenberg Verlag. Hildesheim.

Recycle. Definition 2a. 2017. OED Online. Oxford: Oxford University Press. (www.oed.com/sear ch?searchType=dictionary\&q=recycle\&_search Btn=Search) 
Reuse. Definition 1. 2017. OED Online. Oxford: Oxford University Press. (www.oed.com/search ?searchType=dictionary\&q=reuse\&_search Btn=Search)

Paynter, S. \& Tite, M., 2001. The Evolution of Glazing Technologies in the Ancient Near East and Egypt. In: The Social Context of Technological Change: Egypt and the Near East, 1650-1550 B.C. (ed. A. J. Shortland). Proceedings of a conference held at St Edmund Hall, Oxford. Oxbow Books. Oxford. 239-254.

Paynter, S. 2008. Experiments in Reconstruction of roman Wood-Fired Glassworking Furnaces: Waste Products and Their Formation Processes. Journal of Glass Studies 50. 271-290.

Paynter, S. \& Jackson, C. 2016. Re-used Roman rubbish: a thousand years of recycling glass. European Journal of Postclassical Archaeologies 6. 31-52.

Peake, J. R. N. \& Freestone, I. C. 2012. Cross-craft Interactions between Metal and Glass Working: Slag Additions to Early Anglo-Saxon Red Glass. Proceedings of SPIEIntegrated Approaches to the Study of Historical Glass. Brussels: SPIE.

Vetropack 2017. Recikliranje stakla. Available at: http://recikliranje-stakla.com/recikliranje stakla/ (Accessed 20 April 2017).

Reade, W. J. \& Privat, K. L. 2016. Chemical characterisation of archaeological glasses from the Hellenistic site of Jebel Khalid, Syria by electron probe microanalysis. Heritage Science 4. 20.

Rehren, T. \& Nixon, S. 2014. Refining gold with glass - an early Islamic technology at Tadmekka, Mali. Journal of Archaeological Science 49. 33-41.

Schibille, N., Sterrett-Krause, A. \& Freestone, I. C. 2017. Glass groups, glass supply and recycling in late Roman Carthage. Archaeological and Anthropological Sciences 9 (6). 1223-1241.

Robertshaw, P., Wood, M., Melchiorre, E., Popelka-Filcoff, R. S. \& Glascock, M. D. 2010. Southern African glass beads: chemistry, glass sources and patterns of trade. Journal of Archaeological Science 37 (8). 1898-1912.

Silvestri, A., Molin, G. \& Salviulo, G. 2008a. The colourless glass of Iulia Felix. Journal of Archaeological Science 35. 331-341.

Silvestri, A. 2008b. The coloured glass of Iulia Felix. Journal of Archaeological Science 35. 14891501.

Schibille, N. \& Freestone I. C. 2013. Composition, Production and procurement of Glass at San Vicenzo al Volturno: An early Medieval Monastic Complex in Southern Italy. PLOSone vol.8 issue 10. 1-13.

Shepherd, J. 2015. A Gazetteer of glass working sites in Roman London. In: Glass of the Roman World. (eds. J. Bayley, I. C. Freestone, C. Jackson). Oxbow. Oxford. 33-43.

Shortland, A. J. 2012. Lapis lazuli from the kiln: glass and glassmaking in the late Bronze Age. Studies in archaeological sciences. Leuven: Leuven University Press.

Statius, 2015. Silvae. (trans. J. H. Mozley). Heinemann. London.

Stern, M. 1999. Roman Glassblowing in a Cultural Context. American Journal of Archaeology 103. 441-484.

Stuart, I. 1993. Bottles for Jam? An Example of Recycling from a Post-Contact Archaeological Site. Australian Archaeology 36. 17-21.

Theophilus, On Divers Arts: The Foremost Medieval Treatise on Painting, Glassmaking and Metalwork, (transl. J. G. Hawthorne \& C. Stanley Smith). 1979. Dover Publications. New York.

Walder, H. 2013. Laser Ablation-Inductively Coupled Plasma-Mass Spectrometry (LA-ICP MS) Analysis of Re-fired Glass Pendants from the North American Upper Great Lakes. In: Archaeological Chemistry VIII. (eds. R. A. Armitage \& J. H. Burton). American Chemical Society. Washington. 365-395. 
Wardle, A. M. N., Freestone, I., McKenzie, M. \& Shepherd, J. 2015. Glass Working on the Margins of Roman London: Excavations at 35 Basinghall Street, City of London, 2005. MOLA Monograph 70. London.

Whitehouse, D. 1999. Glass in the Epigrams of Martial. Journal of Glass Studies 41. 73-81.

Venclová, N., Hulínský, V., Henderson, J., Chenery, S., Šulová, L. \& Hložek, J. 2011. Late Bronze Age mixed-alkali glasses from Bohemia. Archeologické rozhledy 63. 559-585.

Wood, M. 2016. Glass beads from pre-European contact sub-Saharan Africa: Peter Francis's work revisited and updated. Archaeological Research in Asia 6. 65-80. 